Journal of Business Finance and Economic (JBFE)

Volume 1, Nomor 1, Juni 2020

http://journal.univetbantara.ac.id/index.php/jbfe

\title{
Pengaruh Kepemimpinan Transformasional, Servant Leadership Dan Pembelajaran Organisasi Pada Kinerja Organisasi
}

\author{
Aprillia Lusiana Wollah ${ }^{1}$ \\ Bambang Nur Cahyaningrum² \\ Ariyani Wahyu Wijayanti ${ }^{3}$ \\ Fakultas Ekonomi, Universitas Veteran Bangun Nusantara ${ }^{123}$ \\ aprillusi161@gmail.com ${ }^{1}$ \\ bambangnurcahyaningrum@gmail.com² \\ aryn.3d071208@gmail.com³
}

\begin{abstract}
This study aims to determine how the influence transformational leadership, servant leadership and organizational learning on organizational performance in restaurants at Wonogiri Regency. The sample used was 154 employees of Restaurants in Wonogiri Regency, including Pak Glinding Restaurant, Titoti Wonogiri Restaurant, Karminah Restaurant, Pondok Dahar Tidar Raos Restaurant, Oke Resto, Pak To Buffet Restaurant, Titoti Ngadirojo Restaurant. Testing the hypothesis in this study using SEM (Structural Equation Modeling). Based on the results of the study, showed that the variables of transformational leadership and servant leadership, have a positive effect on organizational learning. The variable of organizational learning, has a positive effect on organizational performance.
\end{abstract}

Keywords: Transformational leadership, servant leadership, organizational learning, organizational performance.

\section{PENDAHULUAN}

Organisasi yang baik memiliki visi dan misi untuk mencapai tujuan-tujuan yang hendak dicapai. Akan lebih baik apabila organisasi mengalami perbaikan dan perkembangan secara berkelanjutan. Salah satu perbaikan yang diupayakan organisasi adalah meningkatkan atau mempertahankan keunggulan yang dimilikinya. Persaingan di dunia bisnis saat ini semakin ketat, dan dituntut untuk tetap bertahan dalam persaingan tersebut. Pengaruh kepemimpinan pada perusahaan juga berbeda-beda. Salah satu yang dapat dilakukan perusahaan agar mampu bertahan dalam persaingan yang ketat, yaitu meningkatkan kinerja perusahaan dengan mengembangkan dan meningkatkan gaya kepemimpinan pada perusahaan. Kinerja suatu perusahaan 
Journal of Business Finance and Economic (JBFE)

Volume 1, Nomor 1, Juni 2020

http://journal.univetbantara.ac.id/index.php/jbfe

merupakan efisiensi modal, material, peralatan, dan keahlian yang dioptimalkan untuk mengerjakan produksi barang atau jasa perusahaan, sedangkan kinerja organisasi merupakan hasil akumulatif dari semua aktivitas kerja dalam perusahaan (Robbins \& Coulter, 2010). Fenomena yang terjadi pada PT Sido Muncul, konsumsi masyarakat terhadap minuman tradisional berupa jamu terus mengalami penurunan beberapa waktu belakangan. Hal tersebut terlihat dari penurunan penjualan sejumlah perusahaan industri jamu, bahkan hal tersebut juga terjadi pada PT Nyonya Meneer yang mengalami pailit. Tidak hanya PT Nyonya Meneer, penurunan pendapatan dari industri jamu juga dialami oleh PT Industri Jamu dan Farmasi Sido Muncul Tbk. Perusahaan yang berdiri sejak 1970 tersebut, mencatat penurunan penjualan selama semester I-2017 sebesar 6,8\% menjadi Rp 1,2 triliun dari Rp 1,29 triliun pada periode yang sama tahun 2016. Kondisi keuangan perseroan juga mengalami penurunan laba operasi sebesar 8,3\%, dengan penurunan marjin operasi menjadi 24,6\% dari sebelumnya 25\% pada periode yang sama tahun sebelumnya. Laba bersih perseroan tercatat mengalami penurunan sebesar 7,6\%, menjadi Rp 245 miliar dari sebelumnya Rp 265 miliar di 2016 (Situmorang, 2017). Fenomena lain juga terjadi pada toko ritel 7-eleven, dimulai dari pertengahan tahun 2017, masyarakat dihebohkan dengan penutupan seluruh gerai 7-eleven yang mengalami kebangkrutan. 7-eleven resmi menutup seluruh gerainya pada 30 juni 2017, hal ini terjadi karena beberapa faktor terkait kerugian sebesar Rp 447,9 miliar di kuartal 1 pada tahun 2017. Kerugian tersebut bersumber dari salahnya target sasaran dari 7eleven, contoh kecilnya adalah ketika banyak pengunjung yang datang hanya untuk sekedar membeli minuman atau makanan dengan nilai belanja yang tidak besar, namun berlama-lama di gerai 7-eleven serta menikmati fasilitas yang ada. Hal tersebut menyebabkan pemasukan tidak sebanding dengan pengeluaran yang harus dikeluarkan oleh 7-eleven. Selain itu, 7-eleven juga bertentangan dengan pelarangan pemerintah tentang penjualan minuman beralkohol di minimarket. Terkait dengan pelarangan tersebut, 7-eleven terpaksa menarik semua minuman beralkohol, padahal salah satu daya tarik 7-eleven untuk konsumen yang berusia 21 tahun ke atas adalah minuman beralkohol (Setyani, A.N., 2017).

Faktor yang lain adalah servant leadership. Pemimpin yang paling mampu memotivasi pengikutnya adalah pemimpin yang tidak maksimal dalam memuaskan kebutuhan pemimpin itu sendiri, tetapi sebagian besar untuk memprioritaskan 
Journal of Business Finance and Economic (JBFE)

Volume 1, Nomor 1, Juni 2020

http://journal.univetbantara.ac.id/index.php/jbfe

pemenuhan kebutuhan pengikut (Liden et al., 2014). Karyawan yang memiliki pemimpin dengan tipe servant leadership, lebih cenderung termotivasi melakukan inovasi-inovasi baru, untuk mencapai hasil yang diharapkan perusahaan. Sedangkan pembelajaran organisasi merupakan seperangkat perilaku organisasi yang menunjukkan komitmen untuk belajar dan terus melakukan perbaikan. Pembelajaran organisasi merupakan jenis aktivitas dalam organisasi dimana sebuah organisasi belajar (Ortenblad, 2001). Apabila karyawan memiliki kemauan belajar untuk mencapai hasil yang lebih baik dari hasil sebelumnya, maka kinerja organisasi yang dihasilkan akan maksimal.

Penelitian mengenai kinerja organisasi pernah diteliti oleh Morales et al. (2012), yang meneliti pengaruh kepemimpinan transformasional pada kinerja organisasi melalui pembelajaran organisasi dan inovasi pada 168 perusahaan di Spanyol, dengan hasil menujukkan bahwa variabel penelitian saling berhubungan positif yang diantaranya kepemimpinan transformasional, pembelajaran organisasi, inovasi dan kinerja organisasi. Penelitian juga dilakukan oleh Ojokuku et al. (2012), yang meneliti dampak gaya kepemimpinan terhadap kinerja organisasi pada Bank di Ibadan Nigeria. Sebanyak 60 responden dijadikan sampel penelitian tersebut, hasil menunjukkan bahwa gaya kepemimpinan kharismatik dan gaya kepemimpinan birokratis berpengaruh negatif pada kinerja organisasi. Gaya kepemimpinan transaksional dan gaya kepemimpinan autokratis tidak berpengaruh pada kinerja organisasi. Kepemimpinan transformasional berpengaruh positif pada kinerja organisasi. Penelitian serupa juga dilakukan oleh Samad (2012), yang meneliti inovasi dan kepemimpinan transformasional pada kinerja organisasi pada perusahaan logistik di Malaysia. Menggunakan sebanyak 150 responden, hasilnya menunjukkan bahwa inovasi dan kepemimpinan transformasional berhubungan positif dengan kinerja organisasi. Penelitian yang dilakukan oleh Choudhary et al. (2013), meneliti pengaruh kepemimpinan transformasional dan servant leadership pada kinerja organisasi, melalui pembelajaran organisasi. Sampel yang digunakan 155 responden dari perusahaan profit-oriented di Pakistan, dengan hasil menunjukkan bahwa kepemimpinan transformasional dan servant leadership berpengaruh positif pada pembelajaran organisasi, pembelajaran organisasi berpengaruh positif pada kinerja organisasi. Penelitian lain juga dilakukan oleh Noruzy et al. (2013) yang meneliti pengaruh kepemimpinan transformasional, pembelajaran organisasi, dan 
Journal of Business Finance and Economic (JBFE)

Volume 1, Nomor 1, Juni 2020

http://journal.univetbantara.ac.id/index.php/jbfe

manajemen pengetahuan terhadap kinerja organisasi melalui inovasi organisasi. Sampel lebih dari 50 karyawan perusahaan manufaktur di Iran. Hasil penelitan menunjukkan kepemimpinan transformasional berhubungan positif dengan pembelajaran organisasi, manajemen pengetahuan, organisasi inovasi, dan kinerja organisasi. Hasil selanjutnya adalah organisasi pembelajaran berhubungan positif dengan manajemen pengetahuan, inovasi organisasi dan kinerja organisasi. Selanjutnya manajemen pengetahuan dan inovasi organisasi berhubungan positif dengan kinerja organisasi.

Penelitian ini mengacu pada penelitian Choudhary et al. (2013), dengan variabel independen kepemimpinan transformasional, servant leadership, pembelajaran organisasi, sedangkan variabel dependennya adalah kinerja organisasi. Berdasarkan latar belakang di atas, judul penelitian yang digunakan penulis adalah "Pengaruh Kepemimpinan Transformasional, Servant Leadership dan Pembelajaran Organisasi pada Kinerja Organisasi”.

\section{KAJIAN PUSTAKA DAN PERUMUSAN HIPOTESIS}

\section{Kinerja Organisasi}

Tujuan utama dari setiap organisasi adalah untuk mempertahankan keunggulan kompetitif (Choudhary et al., 2013). Kinerja adalah hasil akhir dari sebuah aktivitas, sedangkan kinerja organisasi merupakan hasil akumulatif dari semua aktivitas kerja dalam perusahaan (Robbins \& Coulter, 2010). Kinerja organisasi juga didefinisikan sebagai kemampuan organisasi untuk mencapai tujuan yang efektif dan efisien dengan menggunakan sumber daya yang ada (Daft, 2000). Dapat disimpulkan bahwa kinerja organisasi merupakan hal yang penting dalam perusahaan, karena kinerja organisasi digunakan untuk mengukur sejauh mana perusahaan bisa berjalan dengan progres yang baik. Pencapaian tujuan organisasi dapat dilihat dari kinerja organisasi secara keseluruhan baik dalam bidang keuangan, SDM, produksi, penjualan dan lain sebagainya.

\section{Kepemimpinan Transformasional}

Kepemimpinan transformasional adalah gaya kepemimpinan yang memotivasi para karyawan untuk mencapai kinerja yang tinggi dengan mentransformasikan sikap, kepercayaan, dan nilai-nilai pada karyawan (Hamdani \& Handoyo, 2012). Para 
Journal of Business Finance and Economic (JBFE)

Volume 1, Nomor 1, Juni 2020

http://journal.univetbantara.ac.id/index.php/jbfe

pemimpin transformasional menginspirasi para pengikut untuk melampaui keinginan diri sendiri mereka, demi keuntungan organisasi. Para pemimpin yang transformasional memiliki pengaruh yang luar biasa terhadap para pengikutnya. Aspek dari kepemimpinan transformasional adalah para pemimpin dapat memotivasi para pengikut untuk melaksanakan tugas di atas ekspetasi dan melampaui kepentingan diri mereka sendiri, untuk kepentingan organisasi (Robbins \& Judge, 2015). Pemimpin transformasional memiliki karakteristik kharisma (memberikan visi dan misi, menanamkan kebanggaan, memperoleh respek dan kepercayaan), inspirasi (mengkomunikasikan harapan yang tinggi, mengunakan lambang-lambang untuk memfokuskan upaya, mengungkapkan maksud-maksud penting dengan cara yang sederhana), rangsangan intelektual (menggalakkan kecerdasan, rasionalitas, dan pemecahan masalah), dan pertimbangan individu (memberikan perhatian pribadi, memperlakukan tiap karyawan secara individual, melatih dan menasehati bawahannya) (Mondiani, 2012). Berdasarkan pendapat-pendapat tersebut di atas dapat disimpulkan bahwa kepemimpinan transformasional adalah seorang pemimpin yang dapat memberikan perubahan pada karyawan, serta dapat menginspirasi karyawannya, misalnya dengan memberi motivasi pada karyawannya. Berdasarkan uraian di atas, maka penulis membuat hipotesis sebagai berikut:

H1: Kepemimpinan transformasional berpengaruh positif pada pembelajaran organisasi.

\section{Servant Leadership}

Servant Leadership merupakan kepemimpinan yang membahas masalah etika, pengalaman pelanggan, dan keterlibatan karyawan sambil menciptakan budaya organisasi yang unik, di mana pemimpin dan pengikut bersatu untuk mencapai tujuan organisasi tanpa kekuasaan posisional atau otoritatif. Karyawan dipandang sebagai salah satu aset terbesar organisasi, mempertahankan karyawan yang setia dan produktif, meningkatkan laba menjadi tantangan bagi para pimpinan, serta mendorong untuk memahami keterlibatan karyawan (Carter \& Baghurst, 2013). Servant Leadership didasarkan pada premis bahwa pemimpin yang paling mampu memotivasi pengikut adalah pemimpin yang tidak maksimal dalam memuaskan kebutuhan mereka sendiri, dan sebagian besar memprioritaskan untuk pemenuhan kebutuhan pengikutnya (Greenleaf : Liden et al., 2014). Jadi dapat disimpulkan bahwa servant leadership 
Journal of Business Finance and Economic (JBFE)

Volume 1, Nomor 1, Juni 2020

http://journal.univetbantara.ac.id/index.php/jbfe

adalah seorang pemimpin yang lebih mengarahkan kepada sikap, etika, dan budaya organisasi yang lebih baik. Contohnya: mentaati peraturan dalam kantor yang diantaranya mentaati aturan jam kerja dan cara berpakaian. Berdasarkan uraian tersebut di atas, maka penulis mengajukan hipotesis sebagai berikut:

H2 : Servant leadership berpengaruh positif pada pembelajaran organisasi.

\section{Pembelajaran Organisasi}

Pembelajaran organisasi didasarkan pada prinsip-prinsip dasar pembelajaran, yakni menerima dan mengumpulkan informasi, menginterprestasikannya dan bertindak berdasarkan interprestrasi dari informasi tersebut (Herachwati dkk., 2010). Organisasi pembelajaran merupakan sebuah konsep yang memberikan kekuatan bagi sebuah organisasi untuk mampu bertahan menghadapi perkembangan lingkungan. Penerapan organisasi pembelajaran membuat organisasi memiliki fleksibilitas untuk beradaptasi dengan perubahan lingkungan yang semakin dinamis dan sulit diprediksi (Ambarwati, 2003). Pembelajaran organisasi juga dapat digambarkan sebagai seperangkat perilaku organisasi yang menunjukkan komitmen untuk belajar dan terus melakukan perbaikan. Pembelajaran organisasi merupakan jenis aktivitas dalam organisasi di mana sebuah organisasi terus belajar (Ortenblad, 2001). Dari pendapat-pendapat tersebut dapat disimpulkan bahwa pembelajaran organisasi adalah perilaku karyawan yang berkomitmen untuk saling bertukar informasi dan belajar, untuk menjadi lebih baik lagi kedepannya. Berdasarkan uraian tersebut di atas, peneliti mengusulkan hipotesis sebagai berikut:

H3 : Pembelajaran organisasi berpengaruh positif pada kinerja organisasi.

Berdasarkan hipotesis yang dirumuskan, pengaruh antar variabel dapat digambarkan dalam bentuk model penelitian sebagai berikut:

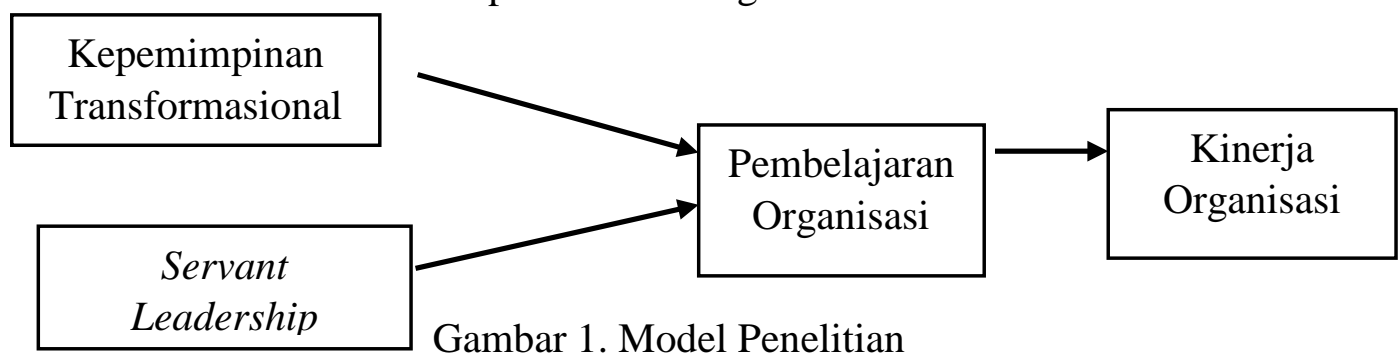

\section{METODE PENELITIAN}

\section{Populasi dan Sampel}


Journal of Business Finance and Economic (JBFE)

Volume 1, Nomor 1, Juni 2020

http://journal.univetbantara.ac.id/index.php/jbfe

Populasi dalam penelitian ini adalah karyawan restoran di Kabupaten Wonogiri.

Sampel yang digunakan adalah 105 karyawan restoran di Kabupaten Wonogiri. Pengambilan sampel dalam penelitian ini menggunakan desain non-probability sampling dengan metode convenience sampling, yakni mengambil sampel secara nyaman dilakukan dengan memilih sampel bebas sekehendak perisetnya (Jogiyanto, 2013). Untuk memperoleh data yang diperlukan, peneliti melakukan penyebaran kuesioner. Total kuesioner yang dibagikan sebanyak 180 kuesioner. Kuesioner yang kembali dan digunakan dalam penelitian ini sebanyak 154 kuesioner. Karakteristik sampel disajikan pada Tabel 1 sebagai berikut :

Tabel 1.

Karakteristik Sampel

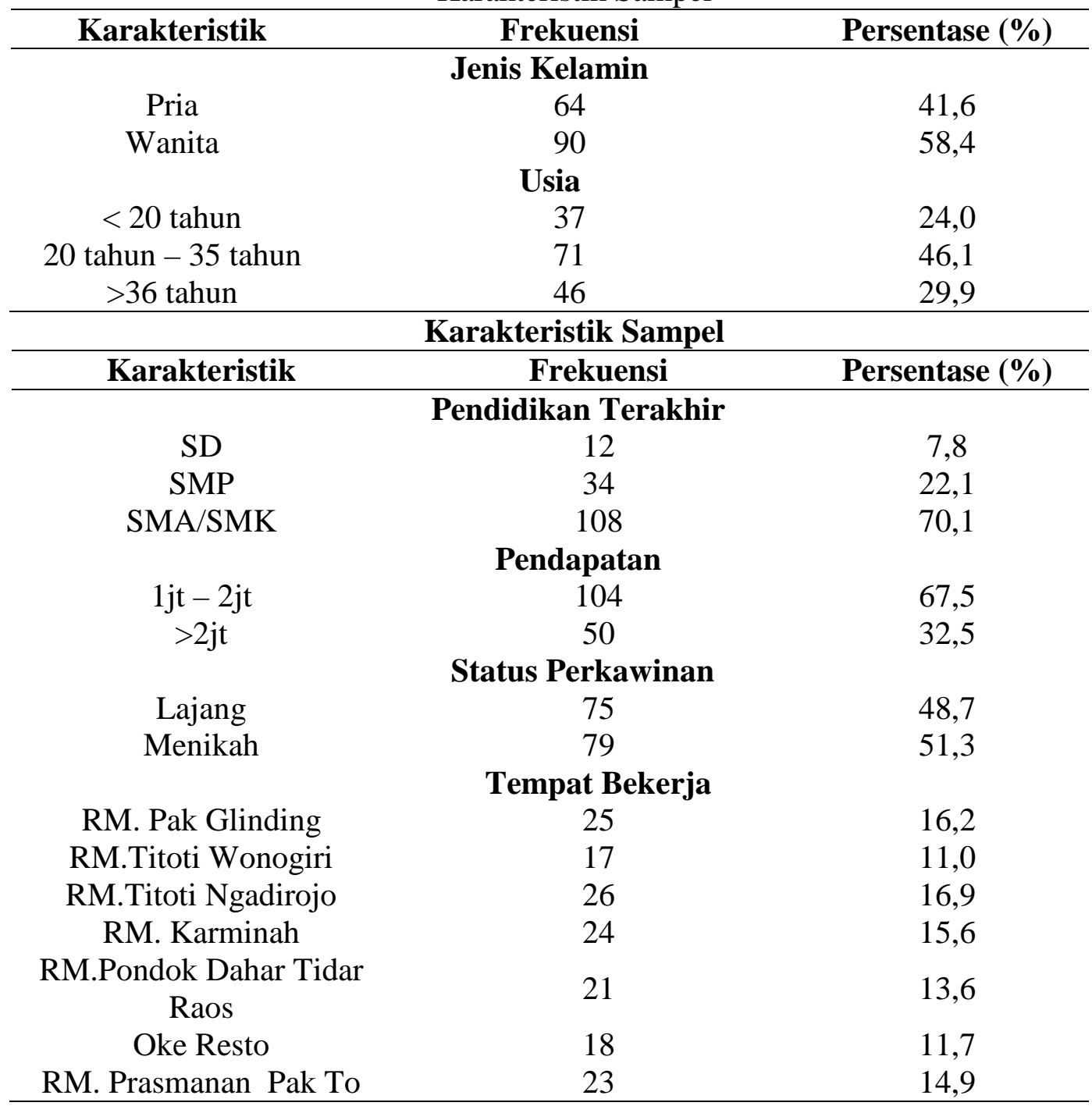

\section{Definisi Operasional dan Pengukuran Variabel}


Journal of Business Finance and Economic (JBFE)

Volume 1, Nomor 1, Juni 2020

http://journal.univetbantara.ac.id/index.php/jbfe

Untuk memberikan gambaran dan pemahaman yang lebih baik, berikut definisi operasional dari masing-masing variable dalam penelitian ini. Setiap item pernyataan yang digunakan, diukur menggunakan Skala Likert dengan 5 alternatif pilihan, yaitu Sangat Tidak Setuju (STS), Tidak Setuju (TS), Netral (N), Setuju (S) dan Sangat Setuju (SS).

Variabel independen dalam penelitian ini terdiri dari kepemimpinan transformasional, servant leadership, pembelajaran organisasi dan kinerja organisasi.

1. Kepemimpinan Transformasional

Kepemimpinan yang menginspirasi bawahan untuk melampaui keinginan diri mereka sendiri, demi keuntungan organisasi. Para pemimpin yang transformasional, memiliki pengaruh yang luar biasa terhadap para pengikutnya. Aspek dari kepemimpinan yang transformasional adalah pemimpin yang dapat memotivasi para pengikut untuk melaksanakan di atas ekspektasi dan melampaui kepentingan mereka sendiri, demi kepentingan organisasi (Robbins \& Judge, 2015). Pengukuran Kepemimpinan Transformasional dalam penelitian ini menggunakan empat item pernyataan yang diadopsi dari Morales et al. (2008).

\section{Servant Leadership}

Servant Leadership merupakan kepemimpinan yang membahas masalah etika, pengalaman pelanggan, dan keterlibatan karyawan sambil menciptakan budaya organisasi yang unik di mana pemimpin dan pengikut bersatu, untuk mencapai tujuan organisasi tanpa kekuasaan posisional atau otorotatif. Karyawan dipandang sebagai salah satu aset terbesar organisasi, mempertahankan karyawan yang setia dan produktif. Meningkatkan laba dan keterlibatan karyawan menjadi tantangan bagi pemimpin (Carter \& Baghurst, 2013). Pengukuran Servant Leadership dalam penelitian ini menggunakan sembilan item pernyataan yang diadopsi dari Jacobs (2006).

3. Pembelajaran Organisasi

Pembelajaran organisasi digambarkan sebagai seperangkat perilaku organisasi yang menunjukkan komitmen untuk belajar, dan terus melakukan perbaikan. Pembelajaran organisasi merupakan jenis aktivitas dalam organisasi di mana sebuah organisasi terus belajar (Ortenblad, 2001). Pengukuran Pembelajaran Organisasi dalam penelitian ini menggunakan empat item pernyataan yang diadopsi dari Morales et al. (2008).

4. Variabel Dependen 
Journal of Business Finance and Economic (JBFE)

Volume 1, Nomor 1, Juni 2020

http://journal.univetbantara.ac.id/index.php/jbfe

Kinerja organisasi didefinisikan sebagai kemampuan organisasi untuk mencapai tujuan yang efektif dan efisien dengan menggunakan sumber daya ada (Daft, 2000). Pengukuran kinerja organisasi dalam penelitian ini menggunakan empat item pernyataan yang diadopsi dari Morales et al. (2008).

\section{ANALISIS DAN PEMBAHASAN}

\section{Hasil Uji Instrumen Penelitian}

Pengujian validitas dilakukan pada empat variabel utama dalam penelitian ini, yaitu kepemimpinan transformal, servant leadership, pembelajaran organisasi, dan kinerja organisasi. Hasil uji validitas item-item pernyataan kepemimpinan transformasional berjumlah empat item pernyataan, variabel servant leadership berjumlah sembilan item pernyataan, menunjukkan bahwa tersisa delapan item pernyataan yang memiliki validitas baik. Variabel pembelajaran organisasi terdiri empat item pernyataan, tersisa sebanyak dua item kuesioner yang memiliki validitas baik, kemudian variabel kinerja organisasi berjumlah empat item pernyataan, tersisa tiga item pernyataan yang termasuk dalam validitas baik. Semua nilai yang validitasnya baik, syaratnya adalah nilai loading faktornya di atas 0,50 .

Dalam uji reliabilitas yang dilakukan, didapatkan hasil sebagai berikut: reliabilitas kepemimpinan transformasional cronbach alphanya sebesar 0,935; servant leadership sebesar 0,919; pembelajaran organisasi sebesar 0,744; kinerja organisasi sebesar 0,827. Semua variable reliabel, dengan nilai cronbach alpha di atas 0,6.

\section{Hasil Uji Hipotesis}

Penelitian ini menggunakan metode structural equation modelling (SEM) untuk menguji hipotesis, dibantu dengan perangkat lunak AMOS 6.0. Penelitian ini melakukan two-step process, Langkah pertama menguji goodness-of-fit dari model yang digunakan sebagai dasar dalam SEM. Langkah kedua adalah pengujian hipotesis untuk hubungan antar variabel menggunakan kriteria Critical Ratio (CR). Penjelasan untuk setiap analisis adalah sebagai berikut:

Tabel 2.

Hasil Uji Goodness-of-Fit Model

\begin{tabular}{llll}
\hline $\begin{array}{l}\text { Goodness-of-fit } \\
\text { indices }\end{array}$ & Cut-off Value & Hasil & Evaluasi Model \\
\hline Chi-Square $\left(\chi^{2}\right)$ & $\begin{array}{l}\text { Diharapkan } \\
\text { kecil }\end{array}$ & 181,712 & - \\
$\begin{array}{l}\text { Degrees of } \\
\text { freedom } \\
\text { Probability }\end{array}$ & Positif & 98 & Fit \\
\hline
\end{tabular}


Journal of Business Finance and Economic (JBFE)

Volume 1, Nomor 1, Juni 2020

http://journal.univetbantara.ac.id/index.php/jbfe

\begin{tabular}{llll}
\hline level $(p)$ & & & \\
CMN/DF & $\leq 2,0$ & 1,854 & Fit \\
GFI & $\geq 0,90$ & 0,880 & Belum memenuhi \\
AGFI & $\geq 0,90$ & 0,813 & Belum memenuhi \\
TLI & $\geq 0,90$ & 0,951 & Fit \\
CFI & $\geq 0,90$ & 0,965 & Fit \\
RMSEA & $\leq 0,08$ & 0,075 & Fit \\
\hline
\end{tabular}

\section{Analisis Goodness-of-Fit Model}

Tabel 2 menjelaskan hasil goodness-of-fit dari model penelitian yang digunakan. Dalam uji ini nilai chi-square $\left(\chi^{2}\right)$ menunjukkan nilai signifikansi lebih dari 0,05 dengan nilai Chi-Square $\left(\chi^{2}\right)$ 181,712. Menunjukkan bahwa model penelitian sesuai dan bisa digunakan. Nilai chi-square $\left(\chi^{2}\right)$ sangat sensitif terhadap ukuran sampel, yang berarti indikator lain diperlukan untuk menghasilkan pembenaran tertentu tentang model yang sesuai (Ghozali, 2013). Indeks kesesuaian lainnya yang digunakan adalah CMN/DF= 1,854, Tucker Lewis Index (TLI)= 0,951, Comparative Fit Index $(\mathrm{CFI})=0,880$ dan Root Mean Square Error of Approxmation (RMSEA)= 0,075. Secara umum, model yang digunakan menunjukkan tingkat kesesuaian yang baik.

\section{Analisis Regression Weights}

Tabel 3 menunjukkan hasil pengujian kepemimpinan transformasional, servant leadership, dan pembelajaran organisasi sebagai variabel independen, dan kinerja organisasi sebagai variabel dependen. Terdapat 2 variabel yang berpengaruh pada pembelajaran organisasi yaitu kepemimpinan transformasional dan servant leadership, dan satu variabel berpengaruh pada kinerja organisasi, sehingga H1, H2, dan H3 didukung dalam penelitian ini.

Tabel 3

Regression Weights

\begin{tabular}{|c|c|c|c|c|c|c|}
\hline & & & Estimate & S.E. & C.R. & $\mathbf{P}$ \\
\hline Pembelajaran & $<-$ & Kepemimpinan & ,334 & ,077 & 4,331 & $* * *$ \\
\hline Organisasi & & Transformasional & & & & \\
\hline $\begin{array}{l}\text { Pembelajaran } \\
\text { Organisasi }\end{array}$ & $<--$ & $\begin{array}{l}\text { Servant } \\
\text { Leadership }\end{array}$ & ,314 & 120 & 2,617 & ,009 \\
\hline Kinerja Organisasi & $<-$ & $\begin{array}{l}\text { Pembelajaran } \\
\text { Organisasi }\end{array}$ & ,657 & 118 & 5,580 & $* * *$ \\
\hline
\end{tabular}

\section{Pembahasan}

Kepemimpinan Transformasional berpengaruh positif pada Pembelajaran Organisasi 
Journal of Business Finance and Economic (JBFE)

Volume 1, Nomor 1, Juni 2020

http://journal.univetbantara.ac.id/index.php/jbfe

Berdasarkan Tabel 3 menunjukkan bahwa pengaruh kepemimpinan transformasional pada pembelajaran organisasi mempunyai nilai sig. sebesar 0,000< 0,05, dengan nilai estimate positif. Hal ini berarti bahwa kepemimpinan transformasional berpengaruh positif pada pembelajaran organisasi, sehingga dapat disimpulkan bahwa H1 didukung. Hasil ini dimungkinkan karena pemimpin di restoran selalu mencari peluang baru untuk meningkatkan hasil dan kualitas pada menu-menu baru di restoran. Hal tersebut akan menghasilkan kesuksesan bersama dalam sebuah organisasi maupun pribadi seorang karyawan, karena dengan atasan yang selalu mencari peluang-peluang baru atau menginovasi, akan menimbulkan komitmen para karyawan untuk saling tukar-menukar informasi, dan belajar meningkatkan kualitas dari menumenu di restoran, yang berarti pembelajaran organisasi yang diterapkan, telah sesuai dengan yang diharapkan oleh pihak restoran. Hasil penelitian ini mendukung penelitian yang dilakukan oleh Choudhary et al. (2013) serta Noruzy et al. (2013), dengan hasil yang menunjukkan bahwa kepemimpinan transformasional berpengaruh positif pada pembelajaran organisasi.

\section{Servant Leadership berpengaruh positif pada Pembelajaran Organisasi}

Berdasarkan Tabel 3 menunjukkan bahwa pengaruh servant leadership pada pembelajaran organisasi mempunyai nilai sig. sebesar $0,009<0,05$, dengan nilai estimate positif. Hal ini berarti bahwa servant leadership berpengaruh positif pada pembelajaran organisasi, sehingga dapat disimpulkan bahwa H2 didukung. Hasil ini dimungkinkan pada saat karyawan dipimpin oleh pimpinan dengan gaya servant leadership, karyawan tersebut akan cenderung termotivasi untuk terus melakukan perbaikan pada kinerjanya, dan karyawan ikut terlibat dalam menciptakan budaya untuk melakukan pembelajaran bersama dengan karyawan lainnya. Hal ini dikarenakan servant leadership menganggap karyawan sebagai salah satu aset terbesar dalam organisasi, sehingga perlu difasilitasi dengan baik agar berkembang lebih luas dalam hal kemampuan, pengetahuan, dan ketrampilannya. Hasil penelitian ini mendukung penelitian yang dilakukan oleh Choudhary et al. (2013) serta Srimulyani \& Hutajulu (2013), dengan hasil yang menunjukkan bahwa servant leadership berpengaruh positif terhadap pembelajaran organisasi. 
Journal of Business Finance and Economic (JBFE)

Volume 1, Nomor 1, Juni 2020

http://journal.univetbantara.ac.id/index.php/jbfe

\section{Pembelajaran Organisasi berpengaruh positif pada Kinerja Organisasi}

Berdasarkan Tabel 3 menunjukkan bahwa pengaruh pembelajaran organisasi pada kinerja organisasi mempunyai nilai sig. sebesar $0,000<0,05$, dengan nilai estimasi positif. Hal ini berarti bahwa pembelajaran organisasi berpengaruh positif pada kinerja organisasi, sehingga dapat disimpulkan bahwa H3 didukung. Hasil ini dimungkinkan karena apabila restoran telah memperoleh dan menggunakan banyak pengetahuan baru dan relevan untuk digunakan, maka akan menciptakan keunggulan kompetitif/keunggulan bersaing, hal tersebut bisa berdampak pada kinerja organisasi, seperti meningkatnya laba/aset dalam setiap waktunya, hal ini akan memberikan arti positif bagi kelangsungan hidup restoran dalam jangka panjang atau di masa mendatang Hasil penelitian ini mendukung penelitian yang dilakukan oleh Choudhary et al. (2013) serta Morales et al. (2012), dengan hasil yang menunjukkan bahwa pembelajaran organisasi berpengaruh positif pada kinerja organisasi.

\section{SIMPULAN, KETERBATASAN, DAN SARAN}

Berdasarkan penelitian yang telah dilakukan pada karyawan restoran di Wonogiri, maka dapat diambil kesimpulan bahwa: kepemimpinan transformasional berpengaruh positif pada pembelajaran organisasi, servant leadership berpengaruh positif pada pembelajaran organisasi, dan pembelajaran organisasi berpengaruh positif pada kinerja organisasi.

Penelitian ini juga memiliki keterbatasan yaitu :

1. Penyebaran kuesioner dilakukan oleh pihak ketiga yaitu restoran, sehingga peneliti tidak dapat mengetahui respon langsung dari responden.

2. Tempat yang digunakan untuk penelitian ini hanya berfokus pada beberapa restoran terbaik di Kabupaten Wonogiri, sehingga terdapat keterbatasan dalam menggeneralisasikan kinerja organisasi di restoran pada umumnya, karena hanya mengukur kinerja organisasi di restoran-restoran terbaik di Wonogiri.

3. Karakteristik yang digunakan disini hanya mencakup jenis kelamin, usia, pendapatan, status perkawinan dan tempat bekerja. Untuk selanjutnya diharapkan dapat menambah karakteristik "lama bekerja karyawan”.

Hasil penelitian ini memberikan implikasi bahwa untuk meningkatkan kinerja organisasi pada restoran, dapat dilakukan dengan cara memperhatikan dan 
Journal of Business Finance and Economic (JBFE)

Volume 1, Nomor 1, Juni 2020

http://journal.univetbantara.ac.id/index.php/jbfe

meningkatkan bentuk-bentuk kepemimpinan seperti kepemimpinan transformasional, servant leadership serta pembelajaran organisasi.

\section{DAFTAR PUSTAKA}

Ambarwati, S. D. A. 2003. Mengelola perubahan organisasional: isu peran kepemimpinan transformasional dan organisasi pembelajaran dalam konteks perubahan. Jurnal siasat bisnis, Vol. 8 (2), 155-176.

Carter, D., \& Baghurst, T. 2013. The influence of servant leadership on restaurant employee engagement. Science + Business Media Dorderecht.

Choudhary, A. I., Akhtar, S. A., \& Zaheer, A. 2013. Impact of transformational and servant leadership on organizational performance: a comparative analysis. Journal of business ethics, 2 (116), 433-440.

Dewi, I. C., \& Herachwati, N. 2010. Analisis dampak kepemimpinan transaksional dan transformasional terhadap pembelajaran organisasi pada PT Bangun Satya Wacana Surabaya. Jurnal Manajemen Teori dan Terapan, 2, 1-15.

Ferdinand, Augusty. 2006. Buku Structural Equation Modelling Dalam Penelitian Manajemen. Edisi 5. Semarang: Badan Penerbit Universitas Diponegoro

Ghozali, Imam. 2013. Aplikasi Analisis Multivariate dengan Program IBM SPSS 21. Edisi Ketujuh. Semarang: Badan penerbit-UNDIP

Gunawan, I. 2015. Pengaruh Kepemimpinan Transformasional dan Kepuasan Kerja terhadap Perilaku Kewargaan Organisasi Guru Sekolah Dasar Negeri Kecamatan Kras Kabupaten Kediri. Premiere Educandum, 1 (5),59-79

Hamdani, W., \& Handoyo, S. 2012. Hubungan antara gaya kepemimpinan transformasional dan stres kerja karyawan PDAM surya sembada kota Surabaya. Jurnal psikologi industri dan organisasi, 2(1).

Hartono, Jogiyanto. 2013. Metode Penelitian Bisnis. Edisi 6. Yogyakarta: BPEE

https://m. Merdeka.com/uang/penjualan-kuku-bima-turun-sido-muncul-anjlok-rp-20miliar-html, waktu akses 26 September 2018 pukul 16.07 WIB.

https://www.rappler.com/indonesia/berita/186707-5-toko-ritel-bangkrut-tergerus-tokoonline, waktu akses 7 Oktober 2018 pukul 16.20 WIB.

Liden, R. C., Wayne, S, J., Liao, C., \& Meuser, J. D. 2014. Servant leadership and serving culture: influence on individual and unit performance. Academy of management journal, 5 (57), 1434-1452.

Lopez, S. P., Peon, J. M. M., \& Ordas, C. J. V. 2005. Organizational learning as determining factor in business competitiveness. 1-14.

Mondiani, T. 2012. Pengaruh kepemimpinan transformasional dan kompensasi terhadap kinerja karyawan PT. PLN (Persero) UPJ Semarang. Jurnal administrasi bisnis, 1 (1), 46-54. 
Journal of Business Finance and Economic (JBFE)

Volume 1, Nomor 1, Juni 2020

http://journal.univetbantara.ac.id/index.php/jbfe

Morales, V. J. G., Barrionuevo, M. M. J., \& Gutierrez, L. G. 2012. Transformational leadership influence on organizational performance through organizational learning and innovation. Journal of business research, 65 (2012), 1040-1050.

Noruzy, A., Dalfard, V. M., Azhdari, B., Shirkouhi, S. N., \& Rezazadeh A. Relations between transformational leadership, organizational learning, knowledge management, organizational innovation, and organizational performance : an empirical investigation of manufacturing of firms. 1073-1085.

Ojokuku, R. M., Odetayo, T. A., \& Sajuyigbe, A. S. Impact of leadership style on organizational performance: a case study of nigerian banks. American journal of business and management, 4 (1), 202-207.

Ortenblad, A. 2001. On differences between organizational learning and learning organization. 3 (8), 125-133.

Robbins, P. R., \& Coulter, M. 2010. Manajemen Edisi Kesepuluh. Jakarta : PT Gelora Aksara Pratama.

Robbins, S., P., \& Judge, T., A. 2015. Perilaku organisasi edisi 16. Jakarta Selatan : Salemba empat.

Samad, S. 2012. The influence of innovation and transformational leadership on organizational performance. Procedia-Social and behavioral sciences, 57 (2012), 486-493.

Sekaran, Uma \& Bougie, Roger. 2017. Buku Metode Penelitian Untuk Bisnis. Jilid 1 Edisi 6. Jakarta: Salemba Empat

Srimulyani, V. A., \& Hutajulu, K. T. 2013. Dampak servant leadership terhadap pembelajaran organisasi dan kinerja guru : studi pada guru-guru SMA dan SMK se-Kota Madiun. Jurnal Manajemen Bisnis Indonesia. Vol 1 (1), 42-53.

Sugiyono. 2017. Metode Penelitian Kuantitatif, Kualitatif, dan R\&D. Bandung: Alfabeta. 